\title{
The Global World in the Pre-Modern Era: Lessons from the Past for Our Future With a Focus on the Early Modern Novel Fortunatus (1509)
}

\author{
ALBRECHT CLASSEN \\ Department of German Studies, University of Arizona, Tucson, Az 85721, USA.
}

\begin{abstract}
There are many efforts underway today to investigate the true extent to which the notion of globalism already applied to the pre-modern world. This study reviews some of the major scholarly contributions, examines major historical, social, and literary developments and phenomena in the Middle Ages that lend themselves well to support the argument that early forms of globalism certainly existed, and illustrates this specifically through a close reading of the anonymous German novel Fortunatus, first printed in Augsburg in 1509. The conclusions that can be drawn from this highly popular work, republished and translated many times far into the late seventeenth century, find significant confirmation in even much earlier texts and historical networks. Hence, carefully modified and adapted, the concept of globalism finds confirmation already in the pre-modern world.
\end{abstract}

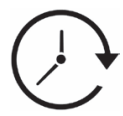

Article History

Received: 28 September 2020

Accepted: 10 December 2020

\author{
Keywords \\ Fortunatus; Global Trade; \\ Globalism in the Pre \\ Modern World; \\ Jesuits; Travel Literature; \\ Translations; \\ Verse Narratives; \\ Wolfram von Eschenbach.
}

Cultural-Historical Globalism: Theoretical Reflections The current scholarly discourse on history, literature, the arts, economics, and politics has assumed a global interest and dimension. Eurocentrism continues to linger, of course, especially in the West, but we find ourselves currently once again in the midst of a paradigm shift that urges us to reexamine everything we do in the Social Sciences and in the Humanities within a much broader framework than before. ${ }^{1}$ This does not mean that we ought to forgo our research interest in European culture, for instance, especially since it certainly continues to influence us in the West very deeply and in many respects, ${ }^{2}$ but we have begun to pursue much broader, universal perspectives today based on mutual respect, acknowledgment, and shared interest on a global scale because humanity is currently at stake, more than ever before, facing profound dangers since we have entered the age of the Anthropocene. ${ }^{3}$ The same statement would be equally relevant for colleagues working in Chinese or African literature and history, for instance, since the world faces many of the same challenges (water, food shortage, pollution, poverty, etc; ${ }^{4}$ And

CONTACT Albrecht Classen 1 aclassen@email.arizona.edu 9 Department Of German Studies, University Of Arizona, Tucson, Az 85721, USA.

\section{(c) (i)}

(C) 2020 The Author(s). Published by Enviro Research Publishers.

This is an 2 Open Access article licensed under a Creative Commons license: Attribution 4.0 International (CC-BY).

Doi: http://dx.doi.org/10.12944/CRJSSH.3.2.04 
it pertains also to the work done in anthropology, music, philosophy, and art history insofar as we have realized that no cultural phenomenon or document can be studied in political or linguistic isolation, if we really intend to carry out a proper assessment of the deeper value and relevance of a visual document or sculpture, a building, a world map, a historical document, a poem, or a piece of music. Nothing seems to stand on its own all by itself, as any careful analysis determined by humanistic criteria quickly demonstrates, revealing countless sources of influences. As I will suggest, all cultural and artistic history is determined by a vertical (past) and by a horizontal (present) vector, and only if we recognize the double directions of human life, will we be able to move forward into our future.

After all, throughout times, people have traded goods, have traveled, have exchanged ideas or experiences, and have collaborated to a greater or a smaller extent, at least wherever that was even possible in the first place due to some proximity and open communications, especially if we consider the contacts between pre-modern Europe and Asia. We obviously do not need to look for connections between the Americas and Africa, or any other continents, prior to the age of world explorations initiated primarily by Europeans and, to some extent, Arabs. However, statements by the various writers, poets, or artists throughout time and from all over the world addressing the fundamental concerns for every individual deserve our full attention if we want to do justice to the central concerns, tasks, and challenges which humanity faces today, more than ever before.

Collaboration and coordination by means of a communicative approach are the critical tasks we must take on if we want to hope for the survival of the human race in a humanistic fashion, which always implies the grounding in historical cultural conditions and values universally shared. This collaboration, however, cannot be limited to our experiences in the present time only; instead the ancient or medieval past holds many answers to central questions of today and tomorrow, if we are willing to listen to the many powerful voices from the pre-modern world, whether in medieval China or medieval Europe. In short, the present endeavors to come to terms with critical global concerns must be predicated on vertical and horizontal perspectives. ${ }^{5}$

\section{Challenges To Becoming Global}

Unfortunately, however, the notion of globalism continues to linger in a theoretical framework and does not easily find constructive reception and concrete realization. For instance, even some of the most recent research on African culture, nationhood, and identity tends to fall back quickly to the same myopic perspectives as in the past and does not take into consideration the global connections. ${ }^{6}$ Of course, we can hardly expect Brazilian or Kazakh scholars to break free from their own cultural framework and embark on more global studies, leaving their own home base behind in favor of abstract approaches to a universal phenomenon. However, in the long run, we can expect that scholars in the widest range of field will come on board and accept that their own research topics and materials must be viewed not only through a local, but also through a global lens because of the infinitude of external sources that always leave their marks, whether directly in a noticeable fashion or only indirectly and then barely recognizable.

Australia, for instance, was completely unknown to the rest of the major parts of the world until the first known landing in Australia in 1606 by the Dutch navigator Willem Janszoon. Nevertheless, the history and culture of Australia long before that date and ever since matters considerably for all of us in the other parts of the world as well because of the universal discourse connecting all people across the globe, as ancient indigenous Australian dream poetry-dreaming tracks-for instance, has vividly demonstrated. ${ }^{7}$ Human life and culture can be described like the Amazon rainforest, with many layers of growth from the roots up to the canopy, populated by countless living creatures. ${ }^{8}$ Of course, many times the mutual influence cannot be easily identified, or might not be specifically present, but if dreaming tracks carry any meaning in the Australian context, then they certainly contribute to the epistemology in other parts of the world as well.

\section{Literature and Globalism: Past and Present}

Yet, how would we then proceed in order to build more meaningful connections and bridges between Australia and other cultures, for instance? To answer this question, we must keep in mind that, after all, the metaphorical forest does not only grow from the bottom to the top, but it extends far and wide 
and thus represents a highly complex biotope or natural habitat. One novella by the German author A. E. Johann, "Der Mann der sein Wort gab" (1950; contained in the collection Zwischen den Ufern), could be a significant opportunity in this regard. The plot is situated in the Northern Territory of Australia, and the author makes considerable efforts to reflect upon the relationship between the white men and the indigenous people, profiling explicitly the latter as the tragic victims of western imperialism, although the Swiss protagonist at the end realizes the devastating consequqences of the white colonialist system and leaves the white world behind together with his indigenous fellow who had rescued his life just at a critical moment after the Swiss had hunted him down.

He had captured the latter in order to bring him to justice for the murder of white settlers, but he finally realizes that the former would never be understood in his cultural frame of mind and would certainly die in prison for a deed which he was not fully culpable of because he had killed the settlers as punishment for their evil deeds against him and his community. This novella might serve as a good example of how new global perspectives could make it possible to communicate between that continent and Europe, between indigenous and western cultures, and between the white capitalist system and the indigenous society (cf. the webpage dedicated to this highly successful author, https:// www.a-e-johann.de/).

These recent discussions about globalism do not mean that we can suddenly assume that medieval Japanese history or the arts can be studied in the same venue as medieval Irish or Spanish complements, and vice versa. It also does not mean that we are now compelled to accept Indian novels or movies as useful parallels to Scandinavian works, and vice versa. The representatives of each culture continue to pursue their own agendas and concerns, and create thus their own identities and social roles. By the same token, this also does not imply at all that we can continue with the traditional compartmentalization as before, which will always leave us with only a tiny part of the holistic whole, our own in a rather parochial manner. Globalism can mean many different things, such as the realization that we exist within a global network and must endeavor to uncover those connections, or the observation that humans throughout time have faced similar concerns, worries, threats, and pursued parallel ideals and desires.

There are, however, also dangers and risks involved. A global perspective might be overly optimistic and bring together aspects or phenomena from very different cultures without any good epistemological justification. It could also mislead us in assuming that peoples from various geographical regions communicated with each other at specific moments in time, when there is no evidence for that. Even though the Mongols, for instance, quickly conquered vast stretches of the Asian and then also the European continent, they were only perceived as a horror by the conquered peoples, and once they disappeared again following Genghis Khan's death in 1227, they were regarded as a bad nightmare that came and left again. ${ }^{9}$

\section{Universal Concerns and Ideals}

Differences in expression or imagery are valuable because they present us with innovative angles, approaches, concepts, and ideas. This means, for instance, that we ought to reflect more on universal issues that address humanity at large, instead of on parochial topics, as burning and urgent as they might be at the present moment. Freedom, for instance, the search for God, the experience of death, the realization of love, friendship, social peace and justice are only some of the central themes that pertain to the Humanities and the Social Sciences on a global level. Different perspectives and cultural frameworks are ubiquitous, of course, so it proves to be rather difficult at times to build meaningful and constructive conversations across linguistic and cultural divides, unless there are shared denominators concerning ethics, morality, ideals, or values.

In a recent project, Japanese and European historians, for instance, or medievalists, have tried to engage in a critical discourse about their shared period of investigation, the Middle Ages, and as fascinating as the outcome proves to be, the challenges are enormous, especially because the mental concepts, methodologies, theoretical approaches, etc., tend not to coincide easily or simply do not overlap. ${ }^{10}$ Even though both worlds were characterized by feudal structures, 
comparisons of cultural and historical phenomena prove to be difficult and often do not yield the desired results. Granted, archetypal parallels are significant, but the outcome of such scholarly efforts still remain somewhat inconclusive and face the danger of comparing the proverbial apples with oranges.

The challenges for scholars and general readers alike in face of global literature are enormous, not only linguistically, but much more critically in cultural, philosophical, religious, and spiritual terms. Fortunately, there are many translations available that allow us to move beyond many different cultural divides, but do we also come prepared to grasp the foundation of the 'other' texts, either from the contemporary world, or from antiquity, the Middle Ages, or the Baroque, to use western chronological terms? Can western viewers easily comprehend what Brazilian, Chinese, or Congolese film makers have expressed cinematographically? How does a Jewish reader manage to come to terms with Buddhistic poetry; how can someone in the Australian Outback enjoy a Peruvian or Bolivian novel deeply predicated on the experiences of the native cultures high up in the Andes? But why not, and why would all this constitute such a problem? Aren't we all people, members of the same human race, all over the globe?11

\section{Medieval Globalism}

In the Middle Ages, all intellectuals conversed in Latin, irrespective of their origin. In the late Middle Ages, Italian gained in preponderance and was also the lingua franca in the Mediterranean, which allowed Christian and Arabic merchants to communicate with each other rather easily. In the seventeenth and eighteenth centuries, French assumed this dominant position, while German claimed this title to some extent in the late nineteenth century, after which British, then American English took over, which is the situation until today. Little wonder that much research on modern cultural globalism has originated from the Anglophone world. Ken Seignurie, the editor of a new multi-volume companion to world literature, alerts us correctly to some of the significant challenges, both past versus present (vertical line) and geographical (horizontal line):

Almost by definition, the texts of world literature are unfamiliar; they stretch our hermeneutic circles, thrust us before unfamiliar genres, modes, forms, and themes. They require a greater degree of attention and focus, and in turn engage our imagination in new ways. Their literary spaces may overlap but little with our own, and we may find that our world is no longer as comfortable and directional as it once was. Some readers of world literature may even embark on learning a new language, seeking passage to a new home-world, bit it temporary or permanent. No wonder societies that love their world discourage and proscribe as much literature as they endorse. ${ }^{12}$

These questions raised here and elsewhere are not limited to the sphere of literature or the arts. The same concerns apply to philosophy and also the sciences, ${ }^{13}$ which really do not know any political or cultural borders. As Bohm (1917-1992) suggested, everything is eternally connected with each other, whether in quantum mechanical terms or not (see the movie Infinite Potential: The Life \& Ideas of David Bohm; online at https://www.infinitepotential.com/). All beings and all objects, all atoms and all genes contain the same life or existence and intimately share the fundamental matter, including the spirit or consciousness, as Georg Friedrich Wilhelm Hegel (1770-1831) had already indicated much earlier with his notion of the Weltgeist (world spirit). ${ }^{14}$

What are then the implications of those concepts already developed in modern physics regarding history, literature, and social sciences? Can we take the monumental leap and break down the barriers between periods, languages, cultural identities, and social entities? Would it be possible to approach all our subject matters through a global lens, or do we then run into the danger of comparing the proverbial apples with oranges? Can we take the risk of drowning ourselves within an ocean of voices, documents, narratives, or images and place them all within the same interlocking space as if they could talk to each other harmoniously, as in Bohm's quantum physics? The contributors to Seigneurie's set of six volumes dealing with global literature were encouraged to do so, and yet the entire project remained a patchwork with most threads not yet meaningfully connected with each other; the noetic knots are simply missing or too elusive. Similarly, other major projects have endeavored to create world history, placing one culture next to each other, 
as if there was only one antiquity, one Middle Ages, one Renaissance, and so forth.

\section{Historical Perspectives}

But the wheels of cultural history run their own course, and when one society finds itself on the rise, another might face a serious decline. The Roman Empire gave way to the Carolingian Empire, which in turn fell apart in a very short time period, while the Arab Empire was much in ascendency. The Holy Roman Empire lasted a long time until 1806, but mostly in name only. The Spanish Empire was replaced by the British Empire, which then had to compete with the Portuguese and Dutch Empires. There is nothing left of any of those, and the French Empire never even achieved a long-lasting success. The Soviet Empire crashed in 1989, and the American Empire is in a considerable decline right now as well, giving way to the new Chinese Empire. ${ }^{15}$ The success of Nazi Germany and of Imperial Japan between 1933 and 1945 was short-lived, but profoundly affected the entire world especially in military terms. In other words, we can gain, after all, many new insights if we pursue a more global, and hence more comparative perspective both in the Humanities and in the Social Sciences because fundamental experiences of mis/fortune, the essence of human existence, the continuous search for meaning and happiness remain the same universally.

Many scholars have tried to identify the emergence of early modern Europe as the result of unique conditions which did not exist in other continents at the same time. ${ }^{16}$ But geographical distance also matters because it can explain why one culture or one people did not interact much with another. The Mongols emerged in the late twelfth century as a major force, and they succeeded in establishing a world empire during a short period of time, after whichthey disappeared once again. ${ }^{17}$ The Chinese witnessed a significant expansion in terms of world trade and travel, when in the early sixteenth century they turned away from the West, defended themselves energetically against the Mongols from the North, and turned primarily toward their own self, thereby basically disappearing from the world scene until their country was 're-discovered' by the Portuguese and then soon other European forces. ${ }^{18}$

Resorting to another dramatic example, we would not be able to understand the history of early medieval Europe without a thorough understanding of the Vikings and their vast exploratory network extending all over Scandinavia to Iceland and Greenland, then to Newfoundland, the British Isles, and from there all along the Atlantic coastlines, the Baltic Sea, the Russian rivers, the Black Sea, and also the Mediterranean. They settled in many parts, such as Southern Italy and Normandy, they looted wherever they could, they left many cultural imprints on the areas where they had attacked or where they settled, and they connected many parts of Europe and even the Near East with each other. There was also a significant number of Viking/lcelandic warriors fighting for the Byzantine emperors, the Varangian Guard, ${ }^{19}$ and the art objects which they pillaged all over Europe were subsequently distributed in the northern countries. But the Vikings were not a unified people; they originated from various parts of Scandinavia, they pursued quite diverse goals and strategies, and they had various degrees of impact on early medieval Europe. ${ }^{20}$

A fairly similar impression was left by the mighty Arab conquerors since the seventh century along the north African coast, to the Iberian Peninsula, and other parts of the Mediterranean, and then far into the Middle East. Even though they were Muslims, they did not represent a unified and historically stable force, though they certainly left behind a considerable cultural imprint on the Christian Europeans. The Arabic world thus extended from the Atlantic shore to the Black Sea, modern-day Iraq and Iran, and even further east. ${ }^{21}$ They were soon joined by, or collided with other peoples from the north and the east, many of them encountering each other in the highly fertile and economically strategic Black Sea region. Both the Venetians and the Genoese, both the Golden Horde and the forces of Tamerlane competed in that part of the world, often in military, but more often in economic and diplomatic terms. ${ }^{22}$

\section{Potentials of Globalism in Critical Scholarship}

The nascent concept of global literary and historical studies thus offers numerous intriguing advantages and innovations, while it is also predicated many times on rather flimsy arguments and might be more the expression of wishful thinking than the results of historical facts. Many historians have always understood that a close focus on local documents, 
conditions, and issues yielded very concrete, solid conclusions and insights. Broader approaches tend to entail risk-taking, assumptions, and theoretical perspectives that might not hold so easily. Pursuing global concepts are certainly most valuable, if they can fulfill what they promise. Simply placing similar events, historical documents, art works, musical compositions, or narratives next to each other only because they then would create a sense of globalism would not amount to much serious scholarship and would only invite considerable speculation. However, both global trade and military conflicts, diplomatic exchanges and missionary activities have been essential activities already in late antiquity and the early Middle Ages, so Global Studies would not replace, but enrich local historical and cultural studies.

Certainly, giving equal weight to Indian, Chinese, Peruvian, Roman, Biblical, or Persian literature composed in late antiquity and the Middle Ages amounts to paying strong respect to the various cultures and proves to be politically correct. However, does such an approach truly contribute to a noetic understanding of parallel developments in literature or the arts? Or does this only amount to adding many puzzle pieces which ultimately do not form a complete picture? Christine Chism points out that "The two universalizing religions of eastern and western Eurasia, Buddhism and Christianity, developed elaborate infrastructures and spread through missionizing movements, while a new ecumenical religion, Islam, arose and spread in a broad swath across western and southern Eurasia and North Africa" (Chism, 2020, p. 675).

Indeed, there were three world religions, but they did not overlap in historical terms, and they never got into touch with each other until the late Middle Ages when Christian missionaries arrived in India and China. Islam, on the other hand, was certainly not an "ecumenical religion," and pursued primarily aggressive strategies to conquer as much of a land mass from the Christians and other religious groups as possible. None of the individual representatives had any significant interest in the other religions; if there was any knowledge of the others at all, then that led only to hostility. Moreover, the outbreak of the pandemic in the middle of the fourteenth century was a shared experience, but this did not lead to any communication across the globe. ${ }^{23}$ We can grant that trade connections existed, especially in the Black Sea and along the northern African shores, but those did not lead to cultural exchanges, perhaps with the exception of several literary cases, such as Barlaam and Josaphat, ${ }^{24}$ or The 1001 Nights. ${ }^{25}$ We are currently extensively probing to what extent translation processes helped build bridges between the various cultures; and in this context we are have become aware about the role of Persia, for instance, in medieval and early modern Europe. ${ }^{26}$ Whether Persian intellectuals had any interest in or harbored any awareness about contemporary Europe, cannot be decided at this point.

Altogether, we increasingly know more about the history of travel, of cultural contacts and exchanges, of trade across continents, of shared ideas, and common efforts against the same enemies or natural challenges. Global Studies promises to become much more than a catchy title in the post-modern climate within the academia if the global perspective is pursued in a critical and solid fashion, not jumping to speculative conclusions while examining the evidence of contacts, translations, mutual influence, etc. as closely as possible.

\section{A Case Study: Fortunatus}

Here I would like to illustrate some of the problems and promises of Global Studies in light of one of the earliest novels in the history of German literature, the anonymous Fortunatus (first printed in Augsburg in 1509), where we come across some meaningful efforts to explore the foreign world and to pursue this effort with a global mindset (quoted from Romane des 15. und 16. Jahrhunderts). ${ }^{27}$

Fortunatus (first printed in Augsburg in 1509) was one of the most popular bestsellers on the early modern German-language market, and it was subsequently also translated into other languages, ${ }^{28}$ such as into English (1676 and 1700), French (1637 and 1659), and intoDutch (1643 and 1700). The British poet Thomas Dekker even created a play based on the German text, The Pleasant Comedie of Old Fortunatus (1599). ${ }^{29}$ In short, here we face a remarkable literary example which appealed to many different readers all over Europe. We might not be able to find any reflections of it in Asian or Arabic countries, but this early novel would still 
deserve to be identified as a major contribution to world literature, although it is completely ignored in the respective volume of the Companion to World Literature. ${ }^{30}$ Unfortunately, what we find in this companion, proves to be just as lopsided in favor of Asian literature as more traditional reference works on world literature were in the past favoring European literature-there are, however, also entries on American, African, and Australian literature. Any efforts to come to terms with global history or global literature thus continue to face severe challenges, and real satisfaction might still be far beyond our reach. ${ }^{31}$

Fortunatus, however, allows us to comprehend much about late medieval and early modern mentality because the novel deals intensively with the emerging capitalistic money-based system, the new possibilities of travel globally, and the rise of new political entities both in East and West. The protagonist originates from Cyprus and travels far west (England) as a young man searching for his fortune. He experiences, however, significant dangers and would at one point have almost faced his death penalty despite his complete innocence. Once having escaped from this critical situation in London, he finds himself in a large forest where he would have almost starved to death, when he encounters a fairy who offers him, magically, a gift. He choose among six options: wisdom, wealth, physical strength, bodily health, beauty, or a long life (p. 450).

Without much hesitation, Fortunatus immediately chooses wealth, which he receives in the form of a simple purse which always contains as much money as he would need. ${ }^{32}$ This money makes it possible for him, after some initial problems that might have cost him his life (once again), to travel all over Europe without any cares, and later, years after he has founded a family and established himself very comfortably back in Cyprus, to tour also Egypt, the Holy Land, and the Middle East, which he calls "die alle dreü jndia haissen" (p. 490; all three of which are called India). The narrator expresses his deep admiration for that exotic world, praising it for the luxury and size, which would dwarf even such great kingdoms or empires such as Persia, China, and Turkey (p. 490). However, he then refrains from going into details because he would not have enough space for them in his book. Instead, he refers to the Travels by John Mandeville and other famous travelogues (pp. 490-91) and then turns to critical reflections about the relationship between the eastern and the western world at large.

We might face here a form of Orientalism avant la letter, but we would not profit much if we engaged with Said's famous theory in light of this early modern German novel because the anonymous poet argues almost counter to this form of imagination ${ }^{33}$ and emphasizes the impossibility of travel and the undesirability and unattractiveness of Europe for Asian people. He admits that the Orient would be highly appealing for Europeans because of the material splendor of the courts, the delicacy of the local food, and the general wealth which they could find there (p. 491). However, most Europeans would not be able to cover the enormous distance to India, particularly since the roads would be so difficult and little maintained. High mountains, wilderness, and the presence of thieves and murderers would make the travel to the East to a highly risky enterprise. But, much more practically, the narrator also realizes that most people would not own enough money to go on such a treacherous and extensive journey. Granted, he believes that enough individuals would have sufficient courage to carry it out, but he knows only too well that the actual costs to spend so much time traveling would be beyond the financial means of most people (p. 491).

Subsequently, the narrator turns around and questions why the Indians would not travel the opposite direction toward Europe. His answers paint a rather negative picture of the Occident where the eastern visitors would encounter a crude and inhospitable culture. Europe would not be a match for India in terms of food, and the weather would be too inclement for the travelers. In fact, the Indians would be regarded as fools by their countrymen for traveling from a good land to a bad land (Europe). Finally, just as in the case of the opposite journey, the long and arduous way would prove to be prohibitive for most, so the global exchange would not take place. Only the protagonist could achieve that goal, especially because he owned enough wealth to go on this enterprise. This makes it even possible for him to leave behind the kingdom of Prester John and to explore that country where they grow pepper 
(p. 491-94: "Lumbert"). The literary medium thus emerges as the critical platform for most readers to experience the global themselves.

This fictional traveler then decides not to go any further since he has seen enough and since he longs for his family back home. The narrator then takes us quickly on the route from somewhere in India back to Egypt and the Sinai Peninsula where Fortunatus visits the monastery St. Catherine, and then turns to Alexandria to see the Sultan there. The two men quickly develop a warm relationship, but this does not prevent Fortunatus later to steal a magical cap from the Sultan with which he can wish himself to any location in the world (pp. 496-98). However, despite these new opportunities to see the rest of the world, the protagonist returns home and spends the rest of his life there without embarking on any new journeys. He has seen, so to speak, enough, and when he falls ill and feels his death coming, he introduces his two sons to the two magical objects and urgesthem to use them wisely.

The second half of the novel treats the life of the two brothers who quickly prove to be obtuse to their deceased father's advice. Especially Andolosia employs both objects intensively, tries to enjoy fun at the various royal courts, and to gain much public esteem. Ultimately, however, he becomes a victim of his own pride and is taken a prisoner and then tortured to death, while Ampedo, the other brother, dies from grief over the disappearanceof his brother.

In his epimythium, the narrator returns to the initial scene with the fairy and strongly advises his audience not to follow Fortunatus's life model. He should have chosen wisdom instead of money which he would have been able to acquire anyway thereby (p. 579). Although he enjoyed endless wealth, his entire life and especially that of his sons was ultimately filled with worries, fears, and trouble, and all of them thus succumbed to death without having found the desired happiness. Wisdom emerges as the ultimate ideal, and the protagonist would have done well if he had chosen it. Unfortunately, as the narrator then concludes, this magical fairy who had offered Fortunatus those options, would no longer exist in this world, which thus closes this chapter on fantasy and imagination. ${ }^{34}$ Nevertheless, the lesson conveyed here still proves to be highly valid, though it was not accepted by the protagonists. While the father faced many dangers in his life and yet could sustain himself successfully because of his precaution and intelligent maneuvering, his sons lack in this regard, fail to display humility, and thus die a miserable death, which concludes this novel, one of the first in early modern German literature with a definitely global character. Many more were to follow in the subsequent decades, parallel to the ever-growing interest in Europe to explore other parts of the world.

\section{Historical Travelers and Explorers}

Even though all the major sea-faring nations in late medieval Europe bordered the sea, primarily German travelers and scientists such as Martin Beheim (1459-1507), the creator of the first globe, or Erdapfel, which he built for the city of Nuremberg in 1492, were actively involved in exploring the spaces beyond the old world. The Bavarian Balthasar Sprenger (d. between 1509 and 1511) accompanied a Portuguese flotilla, under the leadership of the Viceroy Francisco de Almeida, around Africa to India (1505-1506), and he subsequently became the first to write a detailed report about that country based on his eyewitness account. It was printed in 1509 under the exorbitant title DJe Merfart vnd erfarung nüwer Schiffung vnd Wege zuo viln onerkanten Jnseln vnd Künigreichen von dem großmechtigen Portugalischen Kunig Emanuel Erforscht / funden / bestritten vnnd Jngenomen (The Sea Voyage and Exploration of New Travel Passages and Ways to Many Unknown Islands and Kingdoms, on Behalf of the Portuguese King Emanuel, Explored, Discovered, and Investigated). ${ }^{35}$

From here on we could cite countless other travelers who departed from various countries in Europe and explored both Asia and America, and then also Africa. The early modern age was deeply determined by travel and exploration, which launched a truly global enterprise, though it would be an error to assume that in the Middle Ages people did not yet travel, and this already on a global level, such as famous Marco Polo (1254-1324) or Odorico da Pordenone (1286-1331). ${ }^{36}$

Intriguingly, though noted rather rarely, once the Catholic Order of the Jesuits had been founded by Ignatius Loyola in 1540, their missionaries 
established a truly global network for religious purposes which spanned all known continents at that time. Those missionaries were mostly highly educated and demonstrated a great motivation to reach out to the people across the world, learning their languages and helping them to find the way to the Christian God. Whether we could recognize here early forms of colonialism would not need to be discussed here, whereas the Jesuit activities certainly represented a global outreach and at the same time profoundly transformed the European understanding of the other parts of the world ${ }^{37}$

Indeed, the experiences reflected in the anonymous novel Fortunatus clearly anticipated the global efforts which soon were to characterize the early modern world by the Jesuits, merchants, diplomats, and colonialists. Science, religion, economic interests, curiosity, and the strong sense of exploration merged both in the literary context and in reality. However, we still can go one step further backwards to discover incipient forms of globalism. Medieval knights also had roamed many parts of the then known world, as reflected by Wolfram von Eschenbach's courtly romance Parzival (ca. 1205) and by the account provided by Geoffrey Chaucer about the knight in the prologue to his Canterbury Tales (ca. 1400). Despite the fact that these narratives were basically the result of imagination and fantasy, they certainly mirrored the wider history of mentality. While previous research has mostly focused on the history of pilgrimages, we can now draw from a much larger pool of travel authors flourishing already in the high and late Middle Ages. ${ }^{38}$

\section{Globalization in the Pre-Modern Age: Current Research}

Major movements toward globalization prior to our modern age can be identified particularly in the eighth (Vikings), thirteenth (Italian merchants and missionaries), sixteenth (early explorers and Jesuits), and the eighteenth centuries (voyagers and merchatns), as documented by extensive sea faring, international trade, global explorations, and, subsequently, literary reflections upon those new experiences. ${ }^{39}$ However, these efforts to explore the wider world were normally determined by selfish interests and were not predicated on interests to establish communication channels and to exchange ideas and products. Neither the Vikings nor the
Jesuits-certainly an odd coupling of two major groups involved in globalization efforts during the pre-modern time-were truly concerned about and with the people whom they encountered. The former aimed primarily at conquest, plunder, settlement; the latter had their own religion in mind and intended to convert and baptize the native non-Christians all over the world in order to save their lives, a glorification of their own 'altruistic' orientation which ultimately served to satisfy the Jesuits' desire to shine as God's servants here on earth.

We could proceed from here and investigate many other literary texts, art works, historical documents, and objects which all reflected, in one way or the other, the global network to which they owed their existence. The global perspective was always highly interactive, and yet the balance of giving and receiving changed from person to person, from community to community, from culture to culture, and then also from period to period. ${ }^{40}$

In the future, we will probably have the opportunity to understand much more deeply how world literature came about and how it reflected the ongoing globalization processes in pragmatic terms, and this certainly much earlier than in the fifteenth and sixteenth centuries, which many scholars still assume to be the starting point of this phenomenon. ${ }^{41}$ Jamie K. Taylor now deserves credit for her effort to situate Chaucer's "Man of Law's Tale" within a global context, ${ }^{42}$ but much more important would be the fact that already throughout the Middle Ages texts, art works, and ideas moved globally, though we have difficulties until today to trace those movements more precisely. ${ }^{43}$

The vast world of translations, both of medical and philosophical texts, and of literary narratives, connecting Indian, Persian, Arabic, Hebrew, Latin, and then many European literatures with each other. ${ }^{44}$ proves to be a most fertile ground for further studies to explore the true working of globalism in the pre-modern period (for a detailed examination of one branch of knowledge, such as about the medical and spiritual dimension of smell, as it was passed on from the ancient Greeks to the Arabs and then to the Europeans. ${ }^{45}$ In fact, translations were fundamental operations also in economic terms because merchants had to communicate with each 
other, products had to be offered and sold, travels to distant markets had to be organized, and many other commercial activities also required the knowledge of various languages. Economic and literary history are hence surprisingly closely interconnected, and then also tied in to the history of philosophy and religion. ${ }^{46}$

\section{Conclusion}

We are more than aware today that we live in a global world, as the global trade, communication, but then also, tragically, the global pandemic of COVID-19 have dramatically demonstrated. These post-modern experiences are, however, only the continuation of many other global phenomena in the past. Trade, military operations, pilgrimages, missionizing, and exchanges in the field of the sciences, philosophy, the arts, and literature have consistently been predicated and carried out on global connections. It is certainly harder to uncover the pre-modern arteries of the global network than those in our modern world, but there is no doubt that they existed as well, as the evidence of Polo, Odorico, then of countless medieval poets, artists, composers, sculptors, architects, diplomats, and merchants confirms, and this ever more clearly when we turn our attention to the respective documents and probe their hidden data confirming the existence of global exchanges.

In literary-historical terms, we have certainly realizedthe critical importance of examining some of the major collections of religious and didactic narratives composed in Latin during the high and late Middle Ages, such as Petrus Alfonsi's Disciplina clericalis (early twelfth century), Caesarius of Heisterbach Dialogus miraculorum (ca. 1220ca. 1240), or the Gesta Romanorum (middle of the thirteenth century) in light of a variety of Arabic, Persian, and Sanskrit sources, such as the Panchatantra, Khalila and Dimna, and One
Thousand and One Nights. ${ }^{47}$ Boccaccio appears to have been considerably inspired also by nonEuropean sources when he composed his famous Decameron (ca. 1350). Similarly, medieval European history of textiles, art works, sculptures, music, and other areas has also to be studied in light of demonstrable or possible inspirations from the Persian, Arabic, or Syriac cultures.

Of course, we have to be careful not to compare apples with oranges and to relydirectly on the tempting analogy of modern conditions when globalism really took off dramatically (since the eighteenth and nineteenth centuries). However, a careful and sensitive analysis of the many medieval sources indicating the existence of a global exchange of goods, ideas, art works, literary texts, textiles, and so forth both in the Black Sea ${ }^{48}$ and the Mediterranean, which then moved quickly to the northern and western parts of medieval Europe, certainly allows us, if not require from us in many cases, to follow the current epistemological paradigm shift and to grasp the pre-modern world as a crucial stepping stone in the development of a global community, despite serious differences and conflicts, both in military and religious terms, not to speak of the huge language barriers. ${ }^{49}$ The German novel Fortunatus, I would suggest, was obviously a major harbinger of the quantum leap within the ongoing globalization efforts already in the high and late Middle Ages. ${ }^{50}$

\section{Funding}

The author(s) received no financial support for the research, authorship, and/or publication of this article.

\section{Conflict of Interest}

The authors do not have any conflict of interest.

\section{References}

1. Conrad, S. (2016). What is Global History? (Princeton, NJ, and Oxford: Princeton University Press, 2016); Heng, G. (2014). Early Globalities, and Its Questions, Objectives, and Methods: An Inquiry into the State of Theory and Critique.Exemplaria26(2-3), 232-51; Middell, M., ed. (2019). The Practice of Global
History: European Perspectives (London, New York, et al.: Bloomsbury Academic, 2019); Wenzlhuemer, R. (2020). Doing Global History: An Introduction in Six Concepts (London: Bloomsbury Academic, 2020).

2. Curtius, E. (1948/1953/1983/1990). European Literature and the Latin Middle Ages, trans. 
from the German by Willard R. Trask. Bollingen Series, XXXVI (1948; Princeton, NJ: Princeton University Press, 1953, 1983, 1990).

3. Schmidt, J. J. (2020). Water and the Anthropocene: Abundance, Scarcity and Security in the Age of Humanity (New Delhi: Sage, 2018); Harrison, Rodney, and Colin Sterling, ed. Deterritorializing the Future: Heritage in, of and after the Anthropocene (London: Open Humanities Press, 2020).

4. Abba, A. and Onyemachi N. D. (2020). Weeping in the Face of Fortune: Eco-Alienation in the Niger-Delta Ecopoetics. Humanities 2020. 9(3), 54; online at: DOI: 10.3390/h9030054.

5. Classen, A. (2020). Globalism in Medieval Literature? Pre-Modern Perspectives in Poetic Projections: Wolfram von Eschenbach's Parzival, Konrad Fleck's Flore und Blancheflor, and Reinfried von Braunschweig. Athens Journal of Philology7, 1-29.

6. Lachenicht, Susanne, ed. (2019). Future Africa-beyond the Nation. Special Issue of Humanities 2019, https://www.mdpi.com/ journal/humanities/special_issues/africa_nation

7. Chatwin, B. (1987/20112). The Songlines. The Penguin Classics (1987; New York: Penguin Books, 2012); Griffiths, B. (2018). Deep Time Dreaming: Uncovering Ancient Australia (Carlton, Victoria: Schwartz Publishing, 2018).

8. Classen, A. (2020). The Amazon Rainforest of Pre-Modern Literature: Ethics, Values, and Ideals from the Past for our Future. With a Focus on Aristotle and Heinrich Kaufringer. Humanities Open Access 9(1). 4, published on Dec. 24, 2019, online at: file://C:/Users/ aclassen/Downloads/humanities-09-00004.pdf.

9. Turnbull, S. (2003). Genghis Khan \& the Mongol Conquests 1190-1400 (Oxford: Osprey Publishing, 2003); cf. also Lerner, J. D. and Shi, Y., eds. (2020). Silk Roads: From Local Realities to Global Narratives (Oxford and Philadelphia, PA: Oxbow Books, 2020).

10. Ide, M. and Classen, A., ed. (2018). Japanischdeutsche Gespräche über Fremdheit im Mittelalter: Interkulturelle und interdisziplinäre Forschungen in Ost und West. Stauffenburg Mediävistik, 2 (Tübingen: Stauffenburg, 2018).

11. Lupke, Ch., and Nicoll-Johnson, E., ed. (2020). A Companion to World Literature. Vol. 3: 1451 to 1770 (Holboken, NJ, and Chichester, West Sussex: John Wiley \& Sons, 2020). Seigneurie, K. (2020). General Introduction: The Companion to World Literature ... For Those Who Yearn. A Companion to World Literature, ed. id. Vol. 1 (Holboken, NJ, and Chichester, West Sussex: John Wiley \& Sons, 2020), pp. xxvi-xxxiii; here xxvii-xxviii

12. Bohm, D. (2019). The Essential David Bohm, ed. Lee Nichol (London: Routledge, 2003).

13. cf. the contributions to Freire Junior, Olival. David Bohm: A Life Dedicated to Understanding the Quantum World (Cham: Springer, 2019).

14. Salisbury, J. E., ed. (2009). The Greenwood Encyclopedia of Global Medieval Life and Culture. 3 vols (Westport, CT, and London: Greenwood, 2009); Brennan, T. (2008). Postcolonial Studies and Globalization Theory. The Postcolonial and the Global, ed. Revathi Krishnaswarmy and John C. Hawley (Minneapolis, MN: University of Minnesota Press, 2008), 37-53.

15. Aldrich, R., and McKenzie, K., eds. (2014). The Routledge History of Western Empires (London: Routledge, 2014).

16. Mitterauer, M. (2003). Warum Europa? Mittelalterliche Grundlagen eines Sonderwegs (Munich: C. H. Beck, 2003).

17. Ruotsala, A. (2001). Europeans and Mongols in the Middle of the Thirteenth Century: Encountering the Other. Sumalaisen Tiedeakatemian Toimituksia. Annales Academiae Scientiarum Fennicae, Sarja-ser. Humaniora, 314 (Helsinki: The Finnish Academy of Science and Letters, 2001); Cristea, O. and Pilat, L., eds. (2020). From Pax Mongolica to Pax Ottomanica: War, Religion and Trade in the Northwestern Black Sea Region $\left(14^{\text {th }}-16^{\text {th }}\right.$ Centuries). East Central and Eastern Europe in the Middle Ages, 450-1450, 58 (Leiden and Boston: Brill, 2020). They summarize well the relevant research on the history of the Black Sea as a major trading point connecting east with west.

18. Hsia, R. P.-Ch. (2019). From Marco Polo to Matteo Ricci: Sino-Islamic Knowledge and the European Discovery of Cathay. Paradigm Shifts during the Global Middle Ages and the Renaissance, ed. Albrecht Classen. Arizona Studies in the Middle Ages and the Renaissance, 44 (Turnhout: Brepols, 2019), 99-122.

19. D'Amato, R. (2010). The Varangian Guard (Oxford: Osprey, 2010).

20. Mäkeler, H. (2011). Globalisierter Handel um die Jahrhundertwende? Die Ausdehnung des 
winkerzeitlichen Handelsraums. Walter, R., ed. Globalisierung in der Geschichte: Erträge der 23. Arbeitstagung der Gesellschaft für Sozialund Wirtschaftsgeschichte vom 18. bis 21. März 2009 in Kiel. Vierteljahrschrift für Sozial- und Wirtschaftsgeschichte, Beihefte, 214 (Stuttgart: Franz Steiner Verlag, 2011), 15-45.

21. Hoyland, R. G. (2015).In God's Path: The Arab Conquests and the Creation of an Islamic Empire. Ancient Warfare and Civilization (New York: Oxford University Press, 2015).

22. Cristea, O. and Pilat, L., eds. (2020). From Pax Mongolica to Pax Ottomanica (see note 17.

23. Chism, Ch. (2020). Introduction to World Literature: 601 CE to 1450. A Companion to World Literature, ed. Ken Seigneurie. Vol. 2 (Holboken, NJ, and Chichester, West Sussex: John Wiley \& Sons, 2020), 675-84; here 676.

24. Classen, A. (2020).India, Persia, and Arabia in the Mind of a Late Fifteenth-Century German Author: Transcultural Experiences through the Literary Discourse. Antonius von Pforr and his Buch der Beispiele der Alten Weisen. Philological Quarterly99(2), 119-45.

25. Uhlig, M., ed. (2014).D'Orient en Occident: les recueils de fables enchâssées avant les "Mille et une nuits" de Galland (Barlaam et Josaphat, Calila et Dimna, Disciplina clericalis, Roman des sept sages). Cultural Encounters in Late Antiquity and the Middle Ages, 16 (Turnhout: Brepols, 2014); Pollard, E., Rosenberg, C., and Tignor, R. (2015).Worlds Together, Worlds Apart. Vol. 2: From 1000 CE to the Present (New York and London: W. W. Norton, 2015).

26. Barthe, P. (2013). A Seventeenth-Century French Merchant in the Orient: The Portrait of Jean-Baptiste Tavernier in Les six voyages. East Meets West in the Middle Ages and Early Modern Times: Transcultural Experiences in the Premodern World, ed. Albrecht Classen. Fundamentals of Medieval and Early Modern Culture, 14 (Berlin and Boston: Walter de Gruyter, 2013), 758-79; Manning, P. and Owen, A., ed. (2018).Knowledge in Translation: Global Patterns of Scientific Exchange, 1000-1800 CE (Pittsburgh, PA: University of Pittsburgh Press, 2018); Beer, J., ed. (2019). A Companion to Medieval Translation (Leeds: Arc Humanities Press, 2019)

27. Romane des 15. und 16. Jahrhunderts: Nach den Erstdrucken mit sämtlichen Holzschnitten, ed. Jan-Dirk Müller (1990). Bibliothek der Frühen
Neuzeit, 1 (Frankfurt a. M.: Deutscher Klassiker Verlag, 1990).

28. Simon, A. (1987). The Fortunatus Volksbuch in the Light of Later Medieval Travel Literature. Fifteenth-Century Studies 12, 175-86; Kästner, H. (1990). Fortunatus-Peregrinator mundi: Welterfahrung und Selbsterkenntnis im ersten deutschen Prosaroman der Neuzeit. Rombach Wissenschaft-Reihe Litterae (Freiburg i. Br.: Rombach, 1990); Gotzkowsky, B. (1991). "Volksbücher": Prosaromane, Renaissancenovellen, Versdichtungen und Schwankbücher. Bibliographie der deutschen Drucke. Part I: Drucke des 15. und 16. Jahrhunderts. Bibliotheca Bibliographica Aureliana, CXXV (Baden-Baden: Verlag Valentin Koerner, 1991), 420-36; Classen, A. (1994). Die Weltwirkung des Fortunatus: eine komparatistische Studie.Fabula35(3/4), 209-25.

29. Classen, A. (1995). Die Rezeption des deutschen Volksbuchs Fortunatus in England: Thomas Dekkers und seine Dramatisierung des 'Volksbuchs'.NeoheliconXXI(1), 289-311.

30. Seigneurie, K., ed. (2020) (see note 12); Prager, D. (2004). Fortunatus Maps the World and Himself. Wellbery, D., and Ryan, J., ed. A New History of German Literature (Cambridge, MA, and London: The Belknap Press of Harvard University Press, 2004), 194-98.

31. Heng, G., and Ramey, L. (2014). Early Globalities, Global Literatures: Introducing a Special Issue on the Global Middle Ages. Literature Compass, 1-6; online at: 10.1111/ lic3.12156.

32. Bachorski, H.-J.(1983). Geld und soziale Identität im "Fortunatus": Studien zur literarischen Bewältigung frühbürgerlicher Widersprüche. Göppinger Arbeiten zur Germanistik, 376 (Göppingen: Kümmerle, 1983); Van Cleve, J. (1991).The Problem of Wealth in the Literature of Luther's Gemany. Studies in German Literature, Linguistics, and Culture (Columbus, SC: Camden House, 1991); Classen, A. (1995/1999). The German Volksbuch. A Critical History of a Late-Medieval Genre. Studies in German Language and Literature, 15 (Lewiston, NY, Queenston, and Lampeter: Edwin Mellen Press, 1995, reissued 1999), 163-83.

33. Said, E. (1978).Orientalism (London: Routledge, 1978); Khanmohamadi, Sh. A. (2014). In Light of Another's Word: European Ethnography in the Middle Ages. The Middle Ages Series 
(Philadelphia, PA: University of Pennsylvania Press, 2014).

34. Kästner, H. (1990).Fortunatus-Peregrinator mundi (see note 28).

35. Borowka-Clausberg, B. (1999).Balthasar Sprenger und der frühneuzeitliche Reisebericht (Munich: Iudicium, 1999); Classen, A. (2015). India Perceived Through the Eyes of Sixteenth-Century Readers: Ludovico de Varthema's Bestseller on the Early Modern Book Markets-A Narrative Landmark of the Emerging Positive Evaluation of curiositas. Medievalia et Humanistica40, 1-24; Classen, A. (2018). Time, Space, and Travel in the Pre-Modern World: Theoretical and Historical Reflections. An Introduction.Travel, Time, and Space in the Middle Ages and Early Modern Time: Explorations of Worldly Perceptions and Processes of Identity Formation, ed. id. Fundamentals of Medieval and Early Modern Culture, 22 (Berlin and Boston: Walter de Gruyter, 2018), 1-75.

36. See the contributions to Classen, A., ed. (2018). Travel, Time, and Space in the Middle Ages and Early Modern Time (see note 35).

37. Worcester, Th., ed. (2008). The Cambridge Companion to the Jesuits: Overview (Cambridge: Cambridge University Press, 2008); Worcester, Thomas, ed. (2017). Cambridge Encyclopedia of the Jesuits (Cambridge: Cambridge University Press, 2017); de Castelnau-l'Estoile, Charlotte, ed. (2020). Missions d'évangélisation et circulation des saviors XVle - XVIIle siècle (2011; The Hague: OAPEN Foundation, 2020).

38. See, for instance, Legassie, S. A. (2017). The Medieval Invention of Travel (Chicago and London: The University of Chicago Press, 2017).

39. Walter, R. (2011). Globalisierung in der Geschichte-Einführung. Globalisierung in der Geschichte, ed. id. Globalisierung in der Geschichte: Erträge der 23. Arbeitstagung der Gesellschaft für Sozial- und Wirtschaftsgeschichte vom 18. bis 21. März 2009 in Kiel. Vierteljahrschrift für Sozial- und Wirtschaftsgeschichte, Beihefte, 214 (Stuttgart: Franz Steiner Verlag, 2011), pp. 7-13; here p. 9. 40. Osterhammel, J. and Petersson, N. P. (2019).
Geschichte der Globalisierung: Dimensionen, Prozesse, Epochen. 6th ed. (2003; Munich: C. H. Beck, 2019).

41. Ette, O. (2016). TransArea: A Literary History of Globalization, trans. Mark W. Person (Berlin and Boston: Walter de Gruyter, 2016); for a strong counter-perspective to him, see the contributions to Brentjes, S. and Renn, J., ed. (2016). Globalization of Knowledge in the PostAntique Mediterranean, 700-1500 (London and New York: Routledge, 2016).

42. Taylor, J. K. (2020). Toward Premodern Globalism: Oceanic Exemplarity in Chaucer's Man of Law's Tale. PMLA135(2), 254-71.

43. Urry, J. (2007). Mobilities (Cambridge: Polity, 2007); Shichtman, M. B., Finke, L. A., and Kelly, K. (2013). The World is My Home When I'm Mobile': Medieval Mobilities. Postmedieval4 (2), 125-35. Online at: https://link.springer.com/ article/10.1057/pmed.2013.8.

44. Classen, A. (2020). India, Persia (see note 24).

45. Robinson, K. (2020). The Sense of Smell in the Middle Ages: A Source of Certainty. Studies in Medieval History and Culture (London and New York: Routledge, 2020).

46. Manning, P. and Owen, A., ed. (2018).Knowledge in Translation; Beer, J., ed. (2019).A Companion to Medieval Translation (for both, see note 24).

47. Obermaier, S. (2004).Das Fabelbuch als Rahmenerzählung: Intertextualität und Intratextualität als Wege zur Interpretation des Buchs der Beispiele der alten Weisen Antons von Pforr. Beihefte zum Euphorion, 48 (Heidelberg: Universitätsverlag Winter, 2004); Uhlig, M., ed. (2014). D'Orient en Occident (see note 25).

48. Cristea, O. and Pilat, L., eds. (2020). From Pax Mongolica to Pax Ottomanica (see note 17).

49. Standen N. and White, M. (2018). Structural Mobilities in the Global Middle Ages, Past \& Present238(suppl. 13), 158-89.

50. Classen, A. (2013). Fremdbegegnung, Dialog, Austausch, und Staunen: Xenologische Phänomene in der deutschen Literatur des Mittelalters. Vom Hildebrandslied bis zum Fortunatus.Mediaevistik26, 183-206. 